\title{
Death Anxiety and Obsessional Death among University Palestinian Students
}

\author{
Abdelaziz M Thabet ${ }^{1 *}$ and Taysir Abdalla ${ }^{2}$ \\ ${ }^{1}$ School of Public- Consultant Psychiatrist at Child and Family Training and Counseling Center, Al-Quds University, Gaza, Palestine \\ ${ }^{2}$ Al-Quds University, Jerusalem, Gaza, Palestine
}

\begin{abstract}
Aim: The aim of this study was to determine the perception and relationship between death anxiety and death obsession among Palestinians university students. The sample consisted of 216 Palestinian university students enrolled in two universities in Gaza Strip (Al-Al-Azhar and Islamic University of Gaza) and one university in West Bank (Al Quds university of Jerusalem). Eighty-seven of the students (40.3\%) were males and $129(59.7 \%)$ were females. Age ranged from 17 to 30 years. Mean age was 20.4 years $(S D=1.8)$. The researcher used three questionnaires; a predesigned socio- demographic sheet, death anxiety, obsessive about death scale. The study showed that mean death anxiety score was 60.39. The study showed that female student, and those live in Gaza Strip reported more death anxiety. Mean scores on the death obsession was more in students from Gaza. Mean scores of death dominance, death idea repetition, and death ruminations were higher in female's students than males. There was a positive association between death anxiety and death obsession, death dominance, death idea repetition, and death ruminations.

Clinical implications: Our findings that university students had high scores of death anxiety, and obsessive anxiety could be the continuous conflict in the area and repeated exposure to war trauma in the area. Such findings highlight the need for establishing counselling centers in the universities to help students on overcoming their death anxiety and obsession. Also, there is needed for training courses for students in causes and ways of intervention with such problems.
\end{abstract}

Keywords: Death anxiety; Death obsessive; Gaza strip; West bank

\section{Introduction}

In this study we used the Tomer and Eliason's [1] definition death anxiety, they defined death anxiety as a negative emotional reaction provoked by the anticipation of a state in which the self does not exist" (p. 4). Others included in the "anticipation" is dying, which is considered to be part of death anxiety [2]. Templer [3] approached death anxiety as a subjective painful experience common to everyone and originally developed the 15-item self-report Death Anxiety Scale (DAS), which has been widely used and was translated to variety of languages. Abdel-Khalek et al. [4] in study sample of $(\mathrm{N}=601)$ of Palestinians living in the city of Beit Jala, the village of Al-Khader, and the Aida refugee camp in the Bethlehem area. They live in war conditions; the houses of half of them have been demolished. They showed tha Palestinian men and women attained significantly lower DOS mean scores than participants from 4 Arab countries: Egypt, Kuwait, Syria, and Lebanon in 7 out of 8 comparisons. However, Palestinian women had significantly higher DOS mean score than their Spanish, American and British counterparts, whereas Palestinian men had significantly higher mean DOS score than Spanish peers. Such findings were congruent with previous investigations on Kuwaiti and Lebanese participants, but contradicted the non-significant gender differences on the death obsession among Egyptian [5], Syrian [6], American [7], samples. Another review of articles concluded that the most previous studies reported gender differences, with women consistently reporting greater death anxiety than men. Similarly, Kirshenbaum [8] reported higher self-reported death anxiety for women than men. Moreover, Abdel-Khalek [9] reported that female students obtained significantly high scores for the following three items of the scale: fear of hell and doomsday, fear of vague and unknown issues, and torture of the grave. Moreover, Iverach et al. [10] have recently proposed that the dread of death should be viewed as a transdiagnostic construct with the potential to underpin a range of mental disorders. Another study showed that female nurses achieved significantly higher scores on only two items of the scale, particularly, grieving over what they would leave behind (wealth and valuables) and over the loss of self or identity, than female non-nurses Dadfar et al. [11]. Furthermore Asadpour et al. [12] found that the occurrence of death fear was significantly high in the young female nurses in Iran with low work experience, no experience in the intensive care unit (ICU) ward, and no history of death education.

Similarly, Dadfar et al. [13] in study a total of 106 Iranian volunteer nurses were selected from different wards of two hospitals in Tehran, Iran revealed that the mean score of reasons for fear of death among nurses was moderately high. The means for 15 items of the RDFS $(0.83 \%)$ were above midpoint, i.e., 3 .

Another component of death distress is death obsession [5], which he defined it as "repetitive thoughts or ruminations, persistent ideas, or intrusive images that are centered around death of the self or significant others" (p. 160). At the extreme pole of the death obsession continuum, the individuals become obsessed with the notion of death. The Death Obsessive Scale (DOS) was developed by Abdel-Khalek [5]

*Corresponding author: Abdelaziz M Thabet, Emeritus Professor of Psychiatry, School of Public- Consultant Psychiatrist at Child and Family Training and Counseling Center, Al-Quds University, Gaza, Palestine, Tel: + 00970599604400; E-mail: abdelazizt@hotmail.com

Received: January 03, 2018; Accepted: January 10, 2018; Published: January 17, 2018

Citation: Thabet AM, Abdalla T (2018) Death Anxiety and Obsessional Death among University Palestinian Students. Clin Exp Psychol 4: 178. doi: 10.4172/24712701.1000178

Copyright: (C) 2018 Thabet AM, et al. This is an open-access article distributed under he terms of the Creative Commons Attribution License, which permits unrestricted use, distribution, and reproduction in any medium, provided the original author and source are credited. 
as a measure of the third element of the triadic death distress construct that encompasses death anxiety and death depression [14-16]. The factorial structure of the DOS has since been determined in a number of studies using different samples in diverse milieus. All the studies used exploratory factor analysis (EFA), and did so using either principal component (PCA) or principal axis (PA) factoring. Most followed that by oblique rotation of the factors, based on the assumption that the DOS measures a single characteristic, and therefore, its factors are correlated. Finally, a three-factor model was obtained by Abdel Khalek [5] among Egyptian students, Abdel-Khalek et al. [4] among Palestinian refugees [17] using Spanish students, and Mashegoane and Moripe [18] among African students. Only two studies [18] obtained common factors (Death Rumination, Death Dominance and Death Idea Repetition), with completely matching item loadings. Maltby and Day [15] stated that Abdel-Khalek's "Death Obsession Scale was developed to complement research areas, which have investigated death anxiety and death depression and is thought to provide a third element (of which death anxiety and death depression are the other two) to a general concept of death distress" (p. 696).

The relationship between death obsession and anxiety, and other indicators of worry, rumination, and distress from a central personality trait perspective of anxiety or neuroticism. Among seven Egyptian samples, scores on death obsession were significantly higher in anxiety disorder patients than the other clinical groups [9]. Abdel-Khalek [9] in seven Egyptian samples, found that scores on death obsession were significantly higher in anxiety disorder patients than the other clinical groups. Similarly, Maltby and Day [16] used the DOS with two U.K. samples and found statistically significant positive relationships between death obsession and anxiety, depression, and neuroticism. Among American and Arabic undergraduates, death obsession shared a statistically significant positive correlation with anxiety, obsessioncompulsion and ego-grasping orientation, and suicidal ideation [7]. Furthermore, in study South African university students Mashegoane and Moripe [18] compared male and female students' DOS average scores to determine if there were any significant differences. It turned out that there were score differences, with female students scoring comparatively higher mean values on nine of the Death Obsessive Scale items.

Another study found contradictory findings, in study aimed to establish and explore the relationship between gender differences and death obsession to understand increasing suicide statistics, and discuss the impact of marital status, religion and political instability found in Pakistan on death obsession. A convenience sample of 125 participants was selected and Death Obsession Scale (DOS) was administered [5]. The results found significant gender differences in death obsession, with males obtaining a higher mean score $(\mathrm{t}=-1.625, \mathrm{p}<0.019, \mathrm{M}=0.47)$ than females $(M=0.39)$ [19]. Others, Menzies et al. [20] have argued that death anxiety plays a central role in many presentations of Obsessive Compulsive Disorder (OCD), the most prevalent forms of which are dominated by washing and checking behaviors, respectively. Menzies and Dar-Nimrod [21] in study of the relationships between death anxiety and a variety of markers of psychopathology in 171 treatment-seeking participants with Obsessive Compulsive Disorder. Moderate to large correlations between Collett-Lester Fear of Death scale scores, taken at initial assessment, and clinical ratings of OCD severity, number of hospitalizations, number of medications, and total number of lifetime anxiety-related diagnoses identified in structured diagnostic interviews were obtained.

To the best of our knowledge, no research has empirically examined the perception of death anxiety and death obsessive and the relationship between them in Palestinian students to date. Thus, given suggestive evidence of the role of death-related fears in death obsessive we conducted this to address this important area of research in relation to this problem. The first aim of the study was we explored the prevalence of death anxiety and death obsession. The second aim was to find the relationship between death anxiety and death obsession. In the third aim we investigated the socio demographic variables differences in both death anxiety and obsession among Palestinians university students.

\section{Methods}

\section{Participants}

The study sample selected was 216 Palestinian university students enrolled in to two universities in Gaza Strip (Al-Al-Azhar and Islamic University of Gaza) and one university from West Bank (Al Quds university of Jerusalem). Eighty-seven of the participants (40.3\%) were males and $129(59.7 \%)$ were females.

\section{Measures}

\section{A predesigned socio- demographic sheet}

This questionnaire included; gender, age, name of the university, place of residence, and marital status.

\section{The Arabic scale of death anxiety (ASDA)}

The ASDA [14] consists of 20 statements. The scale used a five-point response format, particularly, (1) strongly disagree, (2) disagree, (3) neutral, (4) agree and (5) strongly agree. The score can range from 20 to 100 Alpha reliabilities ranged from 0.88 to 0.93 , and item-remainder correlations ranged between 0.27 and 0.74 ; the 1-week test-retest reliability was 0.90 , denoting high internal consistency and temporal stability. In this study the internal consistency using Chronbach's alpha was 0.90 and split half was 0.84

\section{The Arabic death obsession scale (DOS)}

The DOS [5] contains 15 items with a 5- point Likert-type format, (1) strongly disagree, (2) disagree, (3) neutral, (4) agree and (5) strongly agree. Three factors were disclosed from the DOS: Death Rumination $(3,4,5,7,8,9,10,12)$, Death Domination $(1,2,6,15)$, and Death Idea Repetition $(11,13,14)$ denoting a clear and meaningful factorial structure, interpretable factors, and factorial validity [5]. In this study the internal consistency using Cronbach's alpha was 0.92 and split half was 0.86 .

\section{Data collection procedures}

The researcher implemented structured questionnaires to collect data directly from universities students. The permission was received from the three universities mentioned before. The researcher collected data by trained field workers through coordinated the public relation offices, to the students in the three universities. The students were interviewed in classroom settings in two weeks period in the second semester of the Academic year 2004/2005.

\section{Statistical analysis}

Data analyses were performed using SPSS Version 20 (SPSS, Inc. Chicago, United States). The frequencies of categorical data are presented. Differences in mean scores for death anxiety and death obsession and socio demographic variables were tested using independent $t$ test for two groups and One-way ANOVA for more than three groups. The relationship between death anxiety and death obsession was investigated using the Pearson correlation test. The level of significance was set at $\mathrm{p}<0.05$. 
Citation: Thabet AM, Abdalla T (2018) Death Anxiety and Obsessional Death among University Palestinian Students. Clin Exp Psychol 4: 178. doi: 10.4172/2471-2701.1000178

Page 3 of 5

\section{Results}

\section{Socio-demographic of the study sample}

The results showed that 216 Palestinian university students enrolled in two universities in Gaza Strip (Al-Al-Azhar and Islamic University) and one university from West Bank (Al Quds university of Jerusalem) had been interviewed. Eighty-seven of them (40.3\%) were males and $129(59.7 \%)$ were females. Age ranged from 17 to 30 years, mean age was 20.4 years $(\mathrm{SD}=1.8)$ (Table 1$)$.

\section{Frequency of death anxiety}

The results showed that $59.5 \%$ said they had fears of the torture in their grave, $51.9 \%$ said they had fears of having cancer, $50.5 \%$ said they are worried that death will take someone they love. While the least common items were: Walking in cemetery frightening them $(11 \%)$, upset when seeing funnel $(10.4 \%)$, and afraid visiting the cemetery (9.1\%) (Table 2).

\section{Means and standard deviation of death anxiety}

The study showed that mean death anxiety scores was 60.39 $(\mathrm{SD}=17.57)$.

Sociodemographic differences in death anxiety: The results showed that mean death anxiety in male students was $37.4(\mathrm{SD}=20)$ compared to female mean $=44.9(\mathrm{SD}=18.5)$. Female students significantly reported more death anxiety than male students $(\mathrm{t}(216)=-3.82, \mathrm{p}=0.001)$. Regard place of residence, the results showed that death anxiety in students from Gaza Strip was 62.9 (SD=16.73) compared to $58.10(\mathrm{SD}=18.06)$ from West Bank. There were statistically significant differences in death anxiety toward students from Gaza Strip $(\mathrm{t}(214)=2.04, \mathrm{p}=0.04)$. Regard to university, One Way ANOVA tests using Tukey post hoc test showed

\begin{tabular}{|c|c|c|}
\hline & $\mathrm{N}$ & $\%$ \\
\hline \multicolumn{3}{|c|}{ Sex } \\
\hline Male & 87 & 40.3 \\
\hline Female & 129 & 59.7 \\
\hline Total & 216 & 100 \\
\hline \multicolumn{3}{|c|}{ Age mean $=20.41(S D=1.76)$} \\
\hline \multicolumn{3}{|c|}{ Site of residence } \\
\hline Gaza & 102 & 47.2 \\
\hline West bank & 114 & 52.8 \\
\hline Name of university & 216 & 100 \\
\hline Islamic university & 47 & 21.8 \\
\hline Al Azhar university & 55 & 25.5 \\
\hline $\begin{array}{l}\text { Al Quds university } \\
\text { Jerusalem }\end{array}$ & 114 & 52.8 \\
\hline \multicolumn{3}{|c|}{ Marital status } \\
\hline Single & 197 & 91.2 \\
\hline Married & 18 & 8.3 \\
\hline Divorced & 1 & 0.5 \\
\hline Place of residence & 216 & 100 \\
\hline North west bank & 19 & 8.8 \\
\hline Middle West Bank & 33 & 15.3 \\
\hline South West Bank & 33 & 15.3 \\
\hline Jerusalem & 29 & 13.4 \\
\hline Gaza Strip & 102 & 47.2 \\
\hline \multicolumn{3}{|c|}{ Type of residence } \\
\hline City & 108 & 50 \\
\hline Village & 82 & 38 \\
\hline Camp & 26 & 12 \\
\hline
\end{tabular}

Table 1: Socio-demographic of the study sample $(\mathrm{N}=216)$.

\begin{tabular}{|c|c|c|c|}
\hline Items & $\begin{array}{c}\text { Strongly } \\
\text { agree - } \\
\text { agree }\end{array}$ & Neutral & $\begin{array}{c}\text { Strongly } \\
\text { disagree } \\
- \\
\text { disagree }\end{array}$ \\
\hline 1. I fear death whenever I become ill. & 51.9 & 12.8 & 35.3 \\
\hline 2. I fear looking at the dead. & 53.4 & 13.4 & 33.2 \\
\hline 3. I fear visiting graves. & 72 & 8.8 & 19.3 \\
\hline $\begin{array}{l}\text { 4. The possibility of having a surgical operation } \\
\text { terrifies me. }\end{array}$ & 41.7 & 14.7 & 43.6 \\
\hline 5. I am afraid of suffering a heart attack. & 36.1 & 13.4 & 50.5 \\
\hline $\begin{array}{l}\text { 6. I worry that death may deprive me of someone } \\
\text { dear to me. }\end{array}$ & 17.7 & 6.7 & 75.6 \\
\hline $\begin{array}{l}\text { 7. I am apprehensive of unknown things after } \\
\text { death. }\end{array}$ & 28.6 & 15.2 & 56.1 \\
\hline 8. I am afraid of looking at a corpse. & 51.9 & 11.2 & 36.9 \\
\hline 9. I fear the torture of the grave. & 13.6 & 4.8 & 81.6 \\
\hline 10. I fear getting a serious disease. & 18.2 & 10.4 & 71.4 \\
\hline 11. Witnessing the burial procedure terrifies me. & 51.3 & 13.1 & 35.6 \\
\hline 12. I dread walking in graveyards. & 61.3 & 12.3 & 26.5 \\
\hline $\begin{array}{l}\text { 13. I am preoccupied with thinking about what will } \\
\text { happen after death. }\end{array}$ & 27.3 & 12.3 & 60.5 \\
\hline $\begin{array}{l}\text { 14. I am afraid of sleeping and not waking up } \\
\text { again. }\end{array}$ & 43.3 & 14.2 & 42.5 \\
\hline 15. The pain accompanying death terrifies me. & 28.3 & 13.6 & 58 \\
\hline 16. I get upset by witnessing a funeral. & 58.5 & 20.3 & 21.1 \\
\hline 17. The sight of a dying person frightens me. & 35.9 & 15.2 & 48.9 \\
\hline 18. Talking about death upsets me. & 50.8 & 18.7 & 30.5 \\
\hline 19. I am afraid of getting cancer. & 17.6 & 10.4 & 72 \\
\hline 20. I fear death. & 44.4 & 11 & 44.7 \\
\hline
\end{tabular}

Table 2: Death anxiety items.

that students from Al Azhar university had significantly more than the other two universities (Islamic and AL Quds university) in total scores of death anxiety $(\mathrm{F}(213 / 2)=11.14, \mathrm{p}<0.001)$.

\section{Frequency of death obsession}

The results showed that students commonly reported the following: $45.4 \%$ said some questions about death come to their mind which they were unable to answer, $44.5 \%$ had a feeling that he will die suddenly, $36.61 \%$ were compelled to think about death, $33.4 \%$ recalled alarming and painful aspects of death (Table 3 ).

\section{Means and standard deviation of death obsession scale (DOS)}

Total scores on the DOS was $38.09(\mathrm{SD}=16.24)$.

Sociodemographic differences in death obsession: DOS was higher in female students $(M=39.47)$ than males $(M=36.05), t(214)=-$ $1.52, \mathrm{p}=0.12)$, but not reached statistically significant differences. Death dominance was higher in females students $(\mathrm{M}=12.66)$ than males $(\mathrm{M}=11.06), \mathrm{t}(209)=-2.87, \mathrm{p}=0.006)$. Death Idea Repetition was higher in females students $(M=7.04)$ than males $(M=5.47), t(211)=-3.51$, $\mathrm{p}=0.001$ ) (2-tailed), $\mathrm{d}=1.56$. Death ruminations was higher in females students $(\mathrm{M}=20.13)$ than males $(\mathrm{M}=17.94), \mathrm{t}(209)=-1.83, \mathrm{p}=0.06)$ (Table 4).

Regard site of the study, the results showed that death obsession in students from Gaza Strip was $37.54(\mathrm{SD}=14.49)$ compared to 38.59 (SD 


\begin{tabular}{|c|c|c|c|}
\hline Items & $\begin{array}{c}\text { Strongly } \\
\text { agree - } \\
\text { agree }\end{array}$ & Neutral & $\begin{array}{c}\text { Strongly } \\
\text { disagree } \\
\text {-disagree }\end{array}$ \\
\hline $\begin{array}{l}\text { 1. Some questions about death come } \\
\text { to my mind which I am unable to } \\
\text { answer. }\end{array}$ & 45.4 & 22.2 & 32 \\
\hline $\begin{array}{l}\text { 2. The idea that I will die at a young } \\
\text { age dominates me. }\end{array}$ & 31.5 & 19.4 & 49 \\
\hline $\begin{array}{l}\text { 3. I fail to dismiss the notion of death } \\
\text { from my mind. }\end{array}$ & 29.2 & 14.4 & 56.5 \\
\hline $\begin{array}{l}\text { 4. Thinking about death preoccupies } \\
\text { me. }\end{array}$ & 22.2 & 22.2 & 54.6 \\
\hline $\begin{array}{l}\text { 5. I find it greatly difficult to get rid of } \\
\text { thoughts about death. }\end{array}$ & 18.5 & 13.4 & 67.2 \\
\hline $\begin{array}{l}\text { 6. I recall alarming and painful } \\
\text { aspects of death }\end{array}$ & 33.4 & 21.3 & 44 \\
\hline $\begin{array}{l}\text { 7. I feel I am compelled to think about } \\
\text { death. }\end{array}$ & 36.6 & 13.9 & 48.2 \\
\hline 8. The idea of death overcomes me. & 18.6 & 19.4 & 60.3 \\
\hline $\begin{array}{l}\text { 9. I have exaggerated concern with } \\
\text { the idea of death }\end{array}$ & 15.3 & 13.9 & 69.4 \\
\hline $\begin{array}{l}\text { 10. I find myself rushing to think about } \\
\text { death }\end{array}$ & 18.6 & 16.2 & 64.4 \\
\hline $\begin{array}{l}\text { II. I fear to be dominated by the idea } \\
\text { of death }\end{array}$ & 17.1 & 13.4 & 68.1 \\
\hline 12. I think about death continuously & 19 & 14.8 & 64.4 \\
\hline $\begin{array}{l}13 \text { Thinking about death causes me } \\
\text { much tension }\end{array}$ & 22.7 & 15.3 & 61.1 \\
\hline $\begin{array}{l}\text { 14. The recurrence of the idea of } \\
\text { death annoys me }\end{array}$ & 14.3 & 16.7 & 68 \\
\hline $\begin{array}{l}\text { 15. A feeling that I will die suddenly } \\
\text { overtakes me }\end{array}$ & 44.5 & 18.5 & 35.7 \\
\hline
\end{tabular}

Table 3: The death obsession scale.

\begin{tabular}{|c|c|c|c|c|c|c|}
\hline & Gender & N & Mean & SD & t & p \\
\hline $\begin{array}{c}\text { The Death } \\
\text { Obsession }\end{array}$ & Male & 87 & 36.05 & 18.57 & -1.52 & 0.129 \\
\hline Death dominance & Male & 82 & 11.06 & 4.3 & -2.78 & 0.006 \\
\hline $\begin{array}{c}\text { Death Idea } \\
\text { Repetition }\end{array}$ & Memale & 129 & 12.66 & 3.91 & & \\
\hline & Memale & 128 & 5.47 & 2.91 & -3.51 & 0.001 \\
\hline Death ruminations & Male & 84 & 17.94 & 8.22 & -1.83 & 0.069 \\
\hline & Female & 126 & 20.13 & 8.7 & & \\
\hline
\end{tabular}

Table 4: Sex differences in means and standard deviation of death obsession scale.

$=17.71)$ from West Bank. No statistically significant differences between the two sites ( $\mathrm{t}(214)=0.47, \mathrm{p}=0.63$ ). Regard to name of the university, One Way ANOVA tests using Tukey post hoc test showed that students from Al Azhar university had significantly more than the other two universities (Islamic and AL Quds university) in total scores of death obsession $(\mathrm{F}(213 / 2)=7.72, \mathrm{p}<0.001)$.

\section{Relationships between death anxiety and the death obsession}

Pearson's Correlation Coefficient was used to study the relationship between death anxiety and the death obsession. The results showed that there was a positive association between death anxiety and the death obsession $(r=0.48, p>0.001)$, death dominance $(r=0.45, p>0.001)$, death idea repetition $(\mathrm{r}=0.62, \mathrm{p}>0.001)$, and death ruminations $(\mathrm{r}=0.43$ p $>0.001$ ) (Table 5).

\section{Discussion}

Our study aimed to determine the perception and relationship between death anxiety and death obsession among Palestinians university students The study showed that mean death anxiety score was 60.39 ( $\mathrm{SD}=17.57)$. Our findings of rate of death anxiety were higher than found in Iranian nurses (mean total score was $(57.51 \pm 14.15)$ [13]. Our study showed that mean death anxiety in males was 37.4 compared to female mean=44.9. Gender differences in death anxiety was toward female students. Such gender differences findings were consistent with study of Abdel-Khalek [22] who reported that Egyptian female students obtained significantly high scores for the following three items of the scale: fear of hell and doomsday, fear of vague and unknown issues, and torture of the grave. Also, Abdel-Khalek [9], in study of Kuwaiti sample of undergraduates $(\mathrm{N}=215)$, showed that females had significant tendency to attain higher mean scores on death anxiety, death depression, general anxiety, and general depression in comparison to their male counterparts. Similarly, the study of Iranian older adults found that Iranian women older adults showed higher death distress than men older adults. Tomas-Sabado and GomezBenito [23] reported death anxiety and death depression is related together, but they are distinct aspects of human reactions to the death phenomenon. Moreover, in study of a sample of 2,978 undergraduates took part in the study. Four samples from Arab countries were recruited: Egypt ( $n=418)$, Kuwait ( $n=509)$, Syria $(n=709)$ [24-29] along with three samples from Western countries: Spain $(n=659)$, the United Kingdom $(n=205)$, and the United States $(n=232)$. All the Arab samples had significantly higher mean scores than their Western peers. The effect sizes ranged from small (Lebanon, Spain; Syria, Spain and the United Kingdom) to large effect size (Egypt and Kuwait vs. Spain, the United Kingdom and the United States) [29].

Our study findings were consistent with study of Asadpour et al. [12] which showed that the occurrence of death fear was significantly high in the young female nurses with low work experience, no experience in the intensive care unit (ICU) ward, and no history of death education. Death escape scores were significantly high among the subjects aged 31-35 years. Women with higher education, older than 46 years, and have over 20 years of work experience have a superior approach toward death. Thus, these researchers concluded that their findings could be attributed to religious beliefs and looking at death from a bridge to the afterlife. Similarly, Ayyad [30] found that the nurses who deal with critical cases and work in high-stress wards, such as the ICU, obtained higher mean scores on death distress than the nurses who work in low-stress wards, such as the internal medicine department. Similarly, Thabet et al. [31] in study of Palestinians in Gaza Strip showed that mean death anxiety in males was 37.4 compared to female mean=44.9. Another study showed that female nurses achieved significantly higher scores on only two items of the scale, particularly, grieving over what they would leave behind (wealth and valuables) and over the loss of self or identity, than female non-nurses. Moreover, Abdel-Khalek [9] reported that female students obtained significantly high scores for the following three items of the scale: fear of hell and doomsday, fear of

\begin{tabular}{|l|c|c|c|c|}
\hline & $\mathbf{1}$ & $\mathbf{2}$ & $\mathbf{3}$ & $\mathbf{4}$ \\
\hline $\begin{array}{l}\text { 1.The Arabic Scale of } \\
\text { Death Anxiety (ASDA) }\end{array}$ & 1 & & & \\
\hline $\begin{array}{l}\text { 2.The Death Obsession } \\
\text { Scale (DOS) }\end{array}$ & $0.48^{* *}$ & 1 & & \\
\hline 3.Death dominance & $0.45^{\star *}$ & $0.86^{* *}$ & 1 & \\
\hline 4.Death Idea Repetition & $0.62^{\star *}$ & $0.75^{\star *}$ & $0.52^{* *}$ & 1 \\
\hline 5. Death ruminations & $0.43^{\star *}$ & $0.96^{* *}$ & $0.80^{* *}$ & $0.62^{* *}$ \\
\hline
\end{tabular}

Table 5: Pearson's correlation coefficient between death anxiety and the death obsession. 
Citation: Thabet AM, Abdalla T (2018) Death Anxiety and Obsessional Death among University Palestinian Students. Clin Exp Psychol 4: 178. doi: 10.4172/2471-2701.1000178

Page 5 of 5

vague and unknown issues, and torture of the grave. Abdel-Khalek [27] in study of a sample of 245 volunteer Kuwaiti college students, found gender differences on love of life were not significant. However, women had significantly higher mean scores for the four death distress scales than did their male counterparts.

The study showed that total scores on the DOS were 38.09. AbdelKhalk et al. [4] in study of Palestinian residents of the West Bank showed that death obsession was lower in total sample and were significantly higher in women $(M=28.7)$ than men $(M=23.3)$. Our findings of mean of Death Obsession were higher than finding of death obsession among Kuwait $(\mathrm{n}=271)$ and United Kingdom sample $(\mathrm{n}=205)$ (Mean=30.75 vs. 26.40) [28]. Moreover, our findings of mean of death obsession were higher than found in Iranian nurses (mean total score was $=30.74$ ) $[32,33]$. Gender differences in total DOS and all subscales (death dominance, death idea repetition, and death ruminations) were higher in female students than males. Our findings of gender differences were consistent with study of 1,853 volunteer undergraduates from four Arab countries (Egypt, Kuwait, Lebanon, and Syria) with 791 from three Western countries, i.e., Britain, Spain, and the USA. Comparable Arabic, Spanish, and English versions of the Death Obsession showed that all women samples had higher mean scores than men in the same country, except the British sample; means are nearly identical. The only statistically significant sex differences were found in the Kuwaiti and Lebanese samples. The least difference between men and women was noted for the Syrian sample.

\section{Clinical Implications}

Our findings that university students had high scores of death anxiety, and obsessive anxiety could be the continuous conflict in the area and repeated exposure to war trauma in the area. This study can be generalized on to the current study where Palestine is at constant risk and death-thought primes are easily accessible in the environment in terms of continuous bombardment, sudden violent Israelis strikes, and other political violence faced by people of Palestine on a daily basis.

\section{Conclusion}

In conclusion, the current study emphasizes the importance of meaning in life and to accept the inevitability of death as a reality. Therefore, to have a holistic life it becomes imperative to accept ones mortality and by doing so achieving an authentic and self-fulfilling life. This death acceptance can be achieved by having healthier religious views, increasing companionship and intimacy - thus, providing meaning to life even in adverse conditions. Such findings highlight the need for establishing counselling centers in the universities to help students on overcoming their death anxiety and obsession. Also, there is needed for training courses for students in causes and ways of intervention with such problems.

\section{References}

1. Tomer A, Eliason G (1996) Toward a comprehensive model of death anxiety. Death Stud 20: 343-365.

2. Bennett C (2013) Death anxiety. Encyclopedia of Behavioral Medicine.

3. Templer DI (1970) The construction and validation of a Death Anxiety Scale. J Gen Psychol 82: 165-177.

4. Abdel-Khalek AM, Al-Arja N, Abdalla T (2006) Death Obsession in Palestinians. Death Stud 30: 203-215.

5. Abdel-Khalek AM (1998) The structure and measurement of death obsession. Pers Individ Dif 24: 159-165.

6. Abdel-Khalek AM, Saleh G (1999) Death concern: a comparative study on Syrian samples. Psychol Stu 9: 177-189.

7. Abdel-Khalek AM, Lester D (2003) Death obsession in Kuwaiti and American college students. Death Stud 27: 541-553.

8. Kastenbaum R (2000) The Psychology of Death. Springer Publishing Company

9. Abdel-Khalek AM (2002) Why do we fear death? The construction and validation of the Reasons for Death Fear Scale. Death Stud 26: 669-680.

10. Iverach L, Menzies RG, Menzies RE (2014) Death anxiety and its role in psychopathology: Reviewing the status of a transdiagnostic construct. Clinical Psychology Review 34: 580-593.

11. Dadfar M, Asgharnejad Farid AA, Atef Vahid MK, Lester D, Birashk B (2014) Reasons for fearing death in Iranian nurses. Glob J Adv Pure Appl Sci 4: 335341.

12. Asadpour M, Bidaki R, Rajabi Z, Mostafavi SAM, Khaje-Karimaddini Z, et al. (2015) Attitude toward death in nursing staffs in hospitals of Rafsanjan (south east Iran). Nurs Prac Today 2: 43-51.

13. Dadfar M, Abdel-Khalek AM, Lester D (2017) Psychometric characteristics of the Reasons for Death Fear Scale among Iranian nurses. Int J Nurs Stud 4 384-388.

14. Abdel-Khalek AM, El-Yahfoufi N (2004) Death distress in Lebanese samples. Arabic Stud Psychol 3: 11-30.

15. Maltby J, Day L (2000a) The reliability and validity of the Death Obsession Scale among English university and adult populations. Pers Individ Dif 28: 695700 .

16. Maltby J, Day L (2000b) Religious orientation of Death Obsession. J Genet Psychol 161: 122-124.

17. Tomás-Sábado J, Gómez-Benito J (2005) Construction and validation of the death anxiety inventory (DAI). Eur J Psychol Assess 21: 108-114.

18. Mashegoane S, Moripe S (2013) Structure of the Death Obsession Scale among South African university students. Paper presented at the 7th Annual International Conference on Psychology, Athens, Greece.

19. Zarmeen S, Tahira Y (2015) Gender Differences in Death Obsession. Procedia - Social and Behavioral Sciences 185: 146-150.

20. Menzies RG, Menzies RE, Iverach $L$ (2015) The role of death fears in obsessivecompulsive disorder. Aus Clin Psychol 1: 6-11.

21. Menzies RE, d Ilan Dar-Nimrod I (2017) Death Anxiety and Its Relationship With Obsessive-Compulsive Disorder. J Abnorm Psychol 126: 367-377.

22. Abdel-Khalek AM (2011) Subjective Well-Being and Religiosity in Egyptian College Students. Psychol Rep 118: 54-58.

23. Tomas-Sabado J, Gomez-Benito J (2002) Psychometric properties of the Spanish adaptation of the Death Obsession Scale (DOS). OMEGA-J Death Dying 46: 259-268.

24. Abdel-Khalek AM (2001) Death, anxiety, and depression in Kuwait undergraduates. OMEGA-J Death Dying 42: 309-319.

25. Abdel-Khalek AM (2005) Death obsession in Arabic and Western countries Psycholo Rep 97: 138-140.

26. Abdel-Khalek AM, Tomase Sabado J, Gomez-Benito J (2005) Death anxiety and death depression in Spanish nurses. Psychol Rep 97: 21-24.

27. Abdel-Khalek AM (2007) Love of life and death distress: two separate factors. OMEGA 55: 267-278.

28. Abdel-Khalek AM, Maltby J (2008) The comparison of predictors of death obsession within two cultures. Death Stud 32: 366-377.

29. Abdel-Khalek AM, Lester D, Maltby J, Tomás-Sábado J (2009) The Arabic scale of death anxiety: some results from east and west. OMEGA-J Death Dying 59: 39-50.

30. Ayyad F (2013) Death distress among two samples of lower and higher stress in health care professionals. Psychol Rep 113: 318-327.

31. Thabet AA, Abu Tawahina A, EI Sarraj E, Panos Vostanis (2013) Death Anxiety PTSD, Trauma, Grief, and Mental Health of Palestinians Victims of War on Gaza. Health Care Current Reviews 1: 2.

32. Aghazadeh SE, Mohammadzadeh A, Rezaie A (2014) Validation of death depression scale among tabriz universities students in 2012. J Res Beha Sci 12: 433-420.

33. Dadfar M, Abdel-Khalek AM, Lester D (2016) Psychometric Properties of Farsi Version of the Wish to Be Dead Scale. OMEGA-J Death Dying 76: 78-88. 